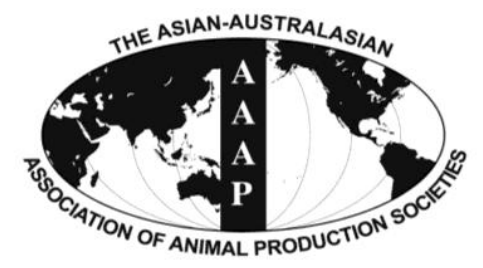

Asian-Aust. J. Anim. Sci.

Vol. 25, No. $3: 401$ - 409

March 2012

www.ajas.info

http://dx.doi.org/10.5713/ajas.2011.11279

\title{
Nutritional Evaluation of Distillery Sludge and Its Effect as a Substitute of Canola Meal on Performance of Broiler Chickens
}

\author{
M. Sharif*, M. A. Shahzad, S. Rehman ${ }^{1}$, S. Khan ${ }^{2}$, R. Ali $^{3}$, M. L. Khan and K. Khan \\ Institute of Animal Nutrition and Feed Technology, University of Agriculture, Faisalabad, Pakistan
}

\begin{abstract}
The study was conducted to investigate the chemical composition of distillery yeast sludge and its inclusion in broiler diets to replace canola meal. Raw distillery yeast sludge was washed with water using water and sludge in the ratio 6:1, respectively. Proximate analysis of raw distillery yeast sludge and washed distillery sludge was carried out for crude protein (CP), true protein (TP), ether extract (EE), ash, acid insoluble ash and nitrogen free extract (NFE) determination. Mineral contents and amino acid profile of raw distillery yeast sludge and washed distillery sludge were also determined. After chemical evaluation, four iso-caloric and iso-nitrogenous broiler starter and finisher diets were prepared in mash form using 0 (control), 4,8 and $12 \%$ levels of washed distillery sludge replacing canola meal. One hundred and twenty day-old broiler chicks were randomly distributed into 12 experimental units in such a way that each diet was offered to three experimental units, each comprising of 10 chicks. It was observed that washing affected the nutrients either by decreasing or increasing their concentration. It decreased the total mineral contents whereas CP, TP, EE and NFE contents increased. Washing also increased amino acid profile. Average feed intake and weight gain were higher in birds fed diet containing $8 \%$ washed distillery sludge and lower in birds fed diet containing $0 \%$ washed distillery sludge. Feed cost per kg live weight gain decreased significantly as the level of washed distillery sludge was increased in the diet. Average heart, liver and pancreas weights decreased with increased level of washed distillery sludge in the diet. The study revealed that after washing, distillery yeast sludge can be used successfully in broiler diets up to the level of $8 \%$ without any adverse effect on broiler's performance. (Key Words : Sludge, Washing, Evaluation, Performance, Dressing Percentage, Broiler)
\end{abstract}

\section{INTRODUCTION}

Poultry industry is one of the fastest growing sectors in developing countries like Pakistan with an average growth rate of 8 to 10 percent annually (Economic Survey, 20092010). Due to rapid increase in human population and poultry production, there is an active competition between human beings and poultry for feed. This results in scarcity and high cost of feedstuffs which contribute poor performance to the poultry as poultry feed accounts for 65 to 75 percent of the total cost of production (Esonu et al., 2006). This unprecedented increase in the cost of conventional feedstuffs has necessitated intensive

\footnotetext{
* Corresponding Author: Muhammasd Sharif.

E-mail : drsharifuaf@yahoo.com

${ }^{1}$ Department of Poultry Science, University of Agriculture, Faisalabad, Pakistan.

${ }^{2}$ Govt Islamia College, Faisalabad, Pakistan.

3 Director Remount Veterinary and Farms GHQ Rawalpindi, Pakistan.
}

Submitted Aug. 12, 2011; Accepted Nov. 2, 2011; Revised Nov. 7, 2011 investigations to explore alternate and non-conventional feed sources available at cheaper rates without reducing the nutritive value of the diet. Production and utilization of single cell protein (SCP) is an important attempt to solve these problems (Shahzad et al., 2011). The term SCP refers to the dead, dried cells of beneficial species of microbes such as yeast, bacteria, fungi, and algae (Ware, 1977). It is characterized by high concentration of nucleotides, inositol and glutamic acid (Silva et al., 2009). Yeast protein has beneficial effect on broiler performance (Silva et al., 2009; Pelícia et al., 2010; Haldar et al., 2011).

Distillery industry produces a great quantity of distillery yeast sludge (DYS), whose management and disposal are environmental problems due to their seasonal availability and some polluting characteristics (Bustamante et al., 2008). Approximately 1,300 tons (dry matter (DM) basis) of DYS is being wasted each year in Pakistan (Khan, 2001) as we consider it to be a toxic waste. Initial studies on the available DYS in Pakistan indicate that it contains great inherent nutritional potential to be utilized as an economical 
source of SCP for poultry, because it has 27 to $29 \%$ crude protein (Ali, 2004). However, it contains exclusively higher mineral content which is the main limitation towards its extensive use. The following study was, therefore, planned to reduce the mineral content of distillery sludge, by washing and to utilize the washed distillery sludge (dried) as a source of protein to replace different levels of canola meal in broiler diets.

\section{MATERIALS AND METHODS}

Experiment was conducted at Animal Nutrition Research Station, University of Agriculture, Faisalabad, Pakistan, to investigate the chemical composition of washed distillery sludge (WDS) and its effect on broiler performance by replacing it with canola meal. Raw distillery yeast sludge (RDS) was washed at the rate of 6:1 (water:sludge). For this, $150 \mathrm{~kg}$ distillery sludge was washed by adding $900 \mathrm{~kg}$ water. The material was placed unmoved for $8 \mathrm{~h}$, which allowed the biomass to settle at the base. After this, water collected above the biomass was removed simply by tilting the container. The biomass remained after washing and removal of water was sun dried. One hundred and fifty square feet floor space was washed to remove dust and the biomass was poured over the area for drying. The flakes of dried WDS were removed by using scraper and ground in the hammer mill to a mash size of 2 mm.

Proximate analysis of RDS and WDS was carried out for crude protein $(\mathrm{CP})$, true protein $(\mathrm{TP})$, ether extract $(\mathrm{EE})$, crude fiber $(\mathrm{CF})$, ash, acid insoluble ash (AIA) and nitrogen free extract (NFE) determination according to the procedure described by AOAC (1990). The gross energy of RDS and WDS were determined by using Parr Adiabatic Oxygen Bomb Calorimeter (Nukamp, 1965), amino acid profile was determined by using Beckman Automatic Amino Acid Analyzer, model 120-C. The RDS and WDS were also analyzed for mineral contents among which calcium, magnesium, manganese, iron, zinc, copper, cobalt and chromium were analyzed by spectrophotometery, sodium and potassium by flame photometer while phosphorus was analyzed photometrically via Spectronic 1001 (Milton Roy Co., Cincinnati, $\mathrm{OH})$.

Four iso-caloric (ME 3,000 kcal/kg DM) and isonitrogenous (CP 22\%) broiler starter diets were prepared in mash form using 0 (control), 4, 8 and 12\% levels of WDS replacing canola meal (Table 3 ). All diets were formulated to cover the nutrient requirements of chicken (NRC, 2001). Similarly, four iso-caloric (ME 3,000 kcal/kg DM) and iso-nitrogenous (CP 20\%) broiler finisher diets were prepared as mash, in the same manner (Table 4).

One hundred and twenty day-old broiler chicks
(Hubbard) were purchased from the local market. The chicks were randomly distributed into 12 experimental units in such a way that each diet was offered to three experimental units, each comprising of 10 chicks. These chicks were then marked for identification. Standard management practices of commercial broiler production were applied. Chicks were vaccinated against New-castle disease at 5 and $25 \mathrm{~d}$ of age and Infectious bursal disease (IB) at 9, 19 and $29 \mathrm{~d}$ of age.

The study lasted for $6 \mathrm{wk}$; 0 to $4 \mathrm{wk}$ for starter phase and 5 to $6 \mathrm{wk}$ for finisher phase. All the experimental birds were weighed at the start of the study and on weekly basis thereafter. All the groups were fed the allotted diets at $\mathrm{ad}$ libitum. Daily feed offered and refused were weighed and at the end of each week, feed consumption was recorded. Feed consumption and weight gain were recorded separately for starter and finisher phase. Feed conversion ratio (FCR) was also calculated for starter and finisher phase. Cumulative data for all feed consumption, weight gain and FCR were calculated. Cost $/ \mathrm{kg}$ of live weight gain was calculated. Mortality was also recorded to determine the survivability percentage.

At the end of the experiment, three birds from each experimental unit were randomly slaughtered to determine the dressing percentage, weights of liver, gizzard, heart, pancreas and thymus and intestinal length.

\section{Statistical analysis}

The data regarding chemical composition of RDS and WDS were analyzed using t-test statistics (Steel et al., 1997), while the data regarding performance trial were analyzed using analysis of variance technique with completely randomized design. The treatment means were compared by least significance difference (LSD) test (Steel et al., 1997).

\section{RESULTS}

\section{Nutritional potential of distillery sludge}

Nutrient composition of RDS and WDS is given in Table 1 and 2. It was observed that washing affects most of the nutrients, either by decreasing or increasing the concentration of the respective nutrient. The data revealed that washing decreased $(46.19 \%)$ the total mineral content significantly $(\mathrm{p}<0.01)$ from 22.08 to $11.88 \%$. The CP, EE and NFE values increased significantly $(\mathrm{p}<0.01)$, as a result of washing. The CP contents of RDS and WDS were 27.40 and $34.80 \%$ which indicated $27 \%$ increase due to washing effect. Similarly, EE and NFE also increased with washing and this increase was 1.10 to $1.20 \%$ and 49.52 to $52.22 \%$, respectively. However, washing didn't affect the CF fraction (Table 1). 
Table 1. Nutrient composition of raw and washed distillery sludge

\begin{tabular}{|c|c|c|c|}
\hline \multirow{2}{*}{ Nutrient $(\%)$} & \multicolumn{2}{|c|}{ Distillery sludge } & \multirow{2}{*}{$\begin{array}{l}\text { Percent increase or decrease } \\
\text { as a result of washing }\end{array}$} \\
\hline & Raw & Washed & \\
\hline \multicolumn{4}{|l|}{ Proximate composition } \\
\hline Metabolizable energy $(\mathrm{kcal} / \mathrm{kg})$ & $2,200^{\mathrm{b}} \pm 20$ & $2,375^{\mathrm{a}} \pm 23.02$ & $\uparrow 7.95$ \\
\hline Crude protein & $27.40^{\mathrm{b}} \pm 0.15$ & $34.80^{\mathrm{a}} \pm 0.20$ & $\uparrow 27.0$ \\
\hline True protein & $18.10^{\mathrm{b}} \pm 0.10$ & $28.20^{\mathrm{a}} \pm 0.13$ & $\uparrow 55.8$ \\
\hline Ether extract & $1.10^{\mathrm{b}} \pm 0.2$ & $1.20^{\mathrm{a}} \pm 0.02$ & $\uparrow 9.09$ \\
\hline Crude fiber & 0.00 & 0.00 & 0.00 \\
\hline Ash & $22.08^{\mathrm{a}} \pm 0.31$ & $11.88^{\mathrm{b}} \pm 0.19$ & $\downarrow 46.19$ \\
\hline Acid soluble ash & $20.10^{\mathrm{a}} \pm 0.27$ & $7.91^{\mathrm{b}} \pm 0.17$ & $\downarrow 60.64$ \\
\hline Nitrogen free extract & $49.52 \pm 0.19$ & $52.22^{\mathrm{a}} \pm 0.07$ & $\uparrow 5.45$ \\
\hline \multicolumn{4}{|l|}{ Mineral contents } \\
\hline Calcium & $3.440^{\mathrm{a}} \pm 0.02$ & $1.330^{\mathrm{b}} \pm 0.001$ & $\downarrow 61.33$ \\
\hline Phosphorus & $1.220^{\mathrm{a}} \pm 0.01$ & $0.550^{\mathrm{b}} \pm 0.01$ & $\downarrow 54.91$ \\
\hline Potassium & $3.520^{\mathrm{a}} \pm 0.02$ & $1.293^{\mathrm{b}} \pm 0.02$ & $\downarrow 63.26$ \\
\hline Sodium & $1.142^{\mathrm{a}} \pm 0.02$ & $0.571^{\mathrm{b}} \pm 0.01$ & $\downarrow 50.0$ \\
\hline Magnesium & $2.000^{\mathrm{a}} \pm 0.01$ & $1.200^{\mathrm{b}} \pm 0.01$ & $\downarrow 40.0$ \\
\hline Manganese & $0.010^{\mathrm{a}} \pm 0.01$ & $0.004^{\mathrm{b}} \pm 0.01$ & $\downarrow 60.0$ \\
\hline Iron & $0.194^{\mathrm{a}} \pm 0.01$ & $0.107^{\mathrm{b}} \pm 0.01$ & $\downarrow 44.84$ \\
\hline Zinc & $0.010^{\mathrm{a}} \pm 0.00$ & $0.008^{\mathrm{b}} \pm 0.00$ & $\downarrow 20.0$ \\
\hline Copper & $0.045^{\mathrm{a}} \pm 0.00$ & $0.033^{\mathrm{b}} \pm 0.00$ & $\downarrow 26.66$ \\
\hline Cobalt & $0.003^{\mathrm{a}} \pm 0.0$ & $0.002^{\mathrm{b}} \pm 0.0$ & $\downarrow 33.33$ \\
\hline Chromium & $0.011 \pm 0.001$ & $0.010 \pm 0.001$ & $\downarrow 9.09$ \\
\hline
\end{tabular}

Means in a row with different superscripts differ significantly $(\mathrm{p}<0.01)$.

The WDS had higher metabolizable energy and TP values than RDS. Washing increased $7.95 \%$ (2,200 to 2,375 $\mathrm{kcal} / \mathrm{kg}$ ) metabolizable energy and $55.80 \%$ (18.10 to $28.20 \%$ ) TP (Table 1) of WDS than RDS. Macro as well as micro minerals exhibited a significant decrease ( $p>0.01)$, as a result of washing. Percent decrease was 61.33 in $\mathrm{Ca}$, 54.91 in $\mathrm{P}, 63.26$ in $\mathrm{K}, 50.00$ in $\mathrm{Na}, 40.00$ in $\mathrm{Mg}, 60.00$ in $\mathrm{Mn}, 44.84$ in $\mathrm{Fe}, 20.00$ in $\mathrm{Zn}, 26.66$ in $\mathrm{Cu}$ and 33.33 in Co. However, washing had non-significant effect on $\mathrm{Cr}$ (Table $1)$.

Washing resulted in significant increase in amino acid profile of WDS. It was observed that washing increased 26 to $27.5 \%$ each amino acid profile (Table 2). However, the ratio among various amino acids remained the same for RDS as well as WDS.

\section{Weight gain}

Average weight gain in birds fed diets containing 0, 4, 8 and $12 \%$ WDS were $910,943,978$ and $969 \mathrm{~g}$, in the starter phase, 560, 562, 719 and $679 \mathrm{~g}$, in the finisher phase and 1,470, 1,505, 1,697 and 1,649 g, 3,048 g, in the starter-cumfinisher phase, respectively (Table 5). During starter phase, the birds fed diets containing 8 and 12\% WDS gained significantly more $(p<0.01)$ weight than those fed diets containing 0 and 4\% WDS. During finisher phase, birds fed diet containing $8 \%$ WDS gained higher $(\mathrm{p}<0.01)$ weight than all other treatments. Overall, the highest live weight gain was observed in birds fed diet containing $8 \%$ WDS.

Table 2. Amino acid profile of raw and washed distillery sludge

\begin{tabular}{lccc}
\hline \multirow{2}{*}{$\begin{array}{c}\text { Amino acid } \\
\text { profile (\%) }\end{array}$} & Raw & Washed & $\begin{array}{c}\text { Percent } \\
\text { increase or } \\
\text { decrease as a } \\
\text { result of } \\
\text { washing }\end{array}$ \\
\cline { 2 - 4 } Lysine & $0.435^{\mathrm{b}} \pm 0.00$ & $0.549^{\mathrm{a}} \pm 0.00$ & $\uparrow 26.20$ \\
Methionine & $0.542^{\mathrm{b}} \pm 0.00$ & $0.689^{\mathrm{a}} \pm 0.00$ & $\uparrow 27.12$ \\
Threonine & $0.827^{\mathrm{b}} \pm 0.01$ & $1.047^{\mathrm{a}} \pm 0.01$ & $\uparrow 26.60$ \\
Arginine & $1.465^{\mathrm{b}} \pm 0.01$ & $1.861^{\mathrm{a}} \pm 0.01$ & $\uparrow 27.03$ \\
Leucine & $1.183^{\mathrm{b}} \pm 0.01$ & $1.503^{\mathrm{a}} \pm 0.01$ & $\uparrow 27.04$ \\
Isoleucine & $1.019^{\mathrm{b}} \pm 0.01$ & $1.294^{\mathrm{a}} \pm 0.01$ & $\uparrow 26.98$ \\
Valine & $0.989^{\mathrm{b}} \pm 0.01$ & $1.252^{\mathrm{a}} \pm 0.01$ & $\uparrow 26.59$ \\
Phenylalanine & $0.912^{\mathrm{b}} \pm 0.01$ & $1.158^{\mathrm{a}} \pm 0.01$ & $\uparrow 26.97$ \\
Histidine & $0.504^{\mathrm{b}} \pm 0.00$ & $0.640^{\mathrm{a}} \pm 0.00$ & $\uparrow 26.98$ \\
Tyrosine & $0.537^{\mathrm{b}} \pm 0.00$ & $0.685^{\mathrm{a}} \pm 0.00$ & $\uparrow 27.56$ \\
Cystine & $1.016^{\mathrm{b}} \pm 0.01$ & $1.291^{\mathrm{a}} \pm 0.01$ & $\uparrow 27.06$ \\
Proline & $0.619^{\mathrm{b}} \pm 0.01$ & $0.786^{\mathrm{a}} \pm 0.01$ & $\uparrow 26.97$ \\
Glutamate & $4.553^{\mathrm{b}} \pm 0.01$ & $5.776^{\mathrm{a}} \pm 0.01$ & $\uparrow 26.86$ \\
Serine & $0.589^{\mathrm{b}} \pm 0.01$ & $0.751^{\mathrm{a}} \pm 0.01$ & $\uparrow 27.50$ \\
Aspartate & $1.726^{\mathrm{b}} \pm 0.01$ & $2.192^{\mathrm{a}} \pm 0.01$ & $\uparrow 26.99$ \\
\hline
\end{tabular}


Table 3. Percent ingredients and nutrient composition of broiler starter diets (0-4 wk)

\begin{tabular}{|c|c|c|c|c|}
\hline \multirow{2}{*}{ Ingredient } & \multicolumn{4}{|c|}{$\mathrm{WDS}^{1}(\%)$} \\
\hline & 0 & 4 & 8 & 12 \\
\hline Canola meal & 12.00 & 8.00 & 4.00 & 0.00 \\
\hline Washed distillery sludge & 0.00 & 4.00 & 8.00 & 12.00 \\
\hline Maize & 38.40 & 39.30 & 40.15 & 40.90 \\
\hline Rice polishing & 15.25 & 15.00 & 14.75 & 14.50 \\
\hline Maize gluten meal $60 \%$ & 4.00 & 4.00 & 4.00 & 4.00 \\
\hline Soyabean meal & 13.70 & 13.60 & 13.50 & 13.40 \\
\hline Cotton seed meal & 5.00 & 5.00 & 5.00 & 5.00 \\
\hline Fish meal & 5.00 & 5.00 & 5.00 & 5.00 \\
\hline Berga fat & 3.55 & 3.10 & 2.70 & 2.40 \\
\hline Limestone & 1.20 & 1.10 & 1.00 & 0.90 \\
\hline Dicalcium phosphate & 1.75 & 1.75 & 1.75 & 1.75 \\
\hline Vitamin mineral premix & 0.15 & 0.15 & 0.15 & 0.15 \\
\hline \multicolumn{5}{|l|}{ Chemical composition $\%$} \\
\hline Metabolizable energy kcal/kg & 3,009 & 3,003 & 3,000 & 3,002 \\
\hline Crude protein & 21.91 & 21.92 & 21.92 & 21.91 \\
\hline Crude fiber & 5.08 & 4.88 & 4.64 & 4.40 \\
\hline Ether extract & 8.12 & 7.57 & 7.02 & 6.47 \\
\hline Calcium & 1.04 & 1.00 & 1.01 & 1.03 \\
\hline Available phosphorus & 0.45 & 0.46 & 0.46 & 0.45 \\
\hline Lysine & 1.10 & 1.00 & 0.91 & 0.81 \\
\hline Methionine & 0.50 & 0.49 & 0.47 & 0.45 \\
\hline
\end{tabular}

${ }^{1} 0,4,8$ and 12 WDS indicates percent inclusion of washed distillery sludge in the diets.

Table 4. Percent ingredients and nutrient composition of broiler finisher diets (5-6 wk)

\begin{tabular}{|c|c|c|c|c|}
\hline \multirow{2}{*}{ Ingredient } & \multicolumn{4}{|c|}{$\mathrm{WDS}^{1}(\%)$} \\
\hline & 0 & 4 & 8 & 12 \\
\hline Canola meal & 12.00 & 8.00 & 4.00 & 0.00 \\
\hline Washed distillery sludge & 0.00 & 4.00 & 8.00 & 12.00 \\
\hline Maize & 45.80 & 46.25 & 46.60 & 47.10 \\
\hline Rice polishing & 16.00 & 16.00 & 16.00 & 16.00 \\
\hline Maize gluten meal $60 \%$ & 4.00 & 4.00 & 4.00 & 4.00 \\
\hline Soyabean meal & 7.50 & 7.40 & 7.30 & 7.25 \\
\hline Cotton seed meal & 5.00 & 5.00 & 5.00 & 5.00 \\
\hline Fish meal & 5.00 & 5.00 & 5.00 & 5.00 \\
\hline Berga fat & 1.85 & 1.60 & 1.45 & 1.10 \\
\hline Limestone & 1.20 & 1.10 & 1.00 & 0.90 \\
\hline Dicalcium phosphate & 1.50 & 1.50 & 1.50 & 1.50 \\
\hline Vitamin mineral premix & 0.15 & 0.15 & 0.15 & 0.15 \\
\hline \multicolumn{5}{|l|}{ Chemical composition (\%) } \\
\hline Metabolizable energy kcal $/ \mathrm{kg}$ & 3,003 & 3,007 & 3,015 & 3,014 \\
\hline Crude protein & 19.89 & 19.89 & 19.87 & 19.89 \\
\hline Crude fiber & 4.98 & 4.76 & 4.52 & 4.29 \\
\hline Ether extract & 6.81 & 6.59 & 5.77 & 5.26 \\
\hline Calcium & 0.93 & 0.91 & 0.92 & 0.91 \\
\hline Available phosphorus & 0.40 & 0.41 & 0.40 & 0.41 \\
\hline Lysine & 1.01 & 0.90 & 0.81 & 0.71 \\
\hline Methionine & 0.40 & 0.39 & 0.36 & 0.35 \\
\hline
\end{tabular}

\footnotetext{
${ }^{1} 0,4,8$ and 12 WDS indicates percent inclusion of washed distillery sludge in the diets.
} 
Table 5. Effects of different levels of washed distillery sludge on body weight gain, feed intake, feed conversion ratio, survival percentage and cost (US \$) per kg weight gain in broiler chickens

\begin{tabular}{|c|c|c|c|c|}
\hline \multirow{2}{*}{ Item } & \multicolumn{4}{|c|}{$\operatorname{WDS}^{1}(\%)$} \\
\hline & 0 & 4 & 8 & 12 \\
\hline \multicolumn{5}{|l|}{$\overline{0-4 \mathrm{wk}}$} \\
\hline Weight gain (g/bird) & $910^{\mathrm{b}} \pm 7.52$ & $943^{\mathrm{ab}} \pm 20.56$ & $978^{\mathrm{a}} \pm 34.99$ & $969^{\mathrm{a}} \pm 6.87$ \\
\hline Feed intake (g/bird) & $1,398^{\mathrm{b}} \pm 29.88$ & $1,444^{\mathrm{ab}} \pm 43.64$ & $1,476^{\mathrm{a}} \pm 39.52$ & $1,503^{\mathrm{a}} \pm 0.60$ \\
\hline FCR & $1.54 \pm 0.02$ & $1.53 \pm 0.01$ & $1.51 \pm 0.01$ & $1.55 \pm 0.01$ \\
\hline Survivability (\%) & $100 \pm 0.00$ & $100 \pm 0.00$ & $100 \pm 0.00$ & $100 \pm 0.00$ \\
\hline Cost (\$) per kg weight gain & $0.44^{\mathrm{a}} \pm 0.24$ & $0.42^{\mathrm{b}} \pm 0.15$ & $0.40^{c} \pm 0.16$ & $0.40^{c} \pm 0.11$ \\
\hline \multicolumn{5}{|l|}{$5-6$ wk } \\
\hline Weight gain (g/bird) & $560^{\mathrm{c}} \pm 10.0$ & $562^{\mathrm{c}} \pm 8.75$ & $719^{\mathrm{a}} \pm 11.45$ & $650^{\mathrm{b}} \pm 3.45$ \\
\hline Feed intake (g/bird) & $1,366^{\mathrm{c}} \pm 35.74$ & $1380^{c} \pm 26.56$ & $1,729^{\mathrm{a}} \pm 4.01$ & $1,545^{\mathrm{b}} \pm 6.01$ \\
\hline FCR & $2.44 \pm 0.02$ & $2.46 \pm 0.01$ & $2.40 \pm 0.04$ & $2.38 \pm 0.02$ \\
\hline Survivability (\%) & $90.00 \pm 0.00$ & $93.33 \pm 5.77$ & $96.66 \pm 5.77$ & $100.0 \pm 0.00$ \\
\hline Cost (\$) per kg weight gain & $0.80^{\mathrm{a}} \pm 2.17$ & $0.70^{\mathrm{b}} \pm 3.35$ & $0.60^{\mathrm{bc}} \pm 1.31$ & $0.56^{c} \pm 0.20$ \\
\hline \multicolumn{5}{|l|}{$0-6$ wk } \\
\hline Weight gain (g/bird) & $1,470^{\mathrm{c}} \pm 15.66$ & $1505^{\mathrm{c}} \pm 24.87$ & $1,697^{\mathrm{a}} \pm 36.05$ & $1,619^{\mathrm{b}} \pm 6.03$ \\
\hline Feed intake (g/bird) & $2,764^{c} \pm 59.96$ & $2824^{\mathrm{c}} \pm 63.27$ & $3,205^{\mathrm{a}} \pm 40.31$ & $3,048^{\mathrm{b}} \pm 6.61$ \\
\hline FCR & $1.88 \pm 0.02$ & $1.88 \pm 0.01$ & $1.89 \pm 0.02$ & $1.88 \pm 0.01$ \\
\hline Survivability (\%) & $90.00 \pm 0.00$ & $93.33 \pm 5.77$ & $96.66 \pm 5.77$ & $100.0 \pm 0.00$ \\
\hline Cost (\$) per kg weight gain & $0.62^{\mathrm{a}} \pm 1.12$ & $0.56^{\mathrm{b}} \pm 1.71$ & $0.50^{\mathrm{c}} \pm 0.61$ & $0.48^{\mathrm{c}} \pm 0.10$ \\
\hline
\end{tabular}

${ }^{1} 0,4,8$ and 12 WDS indicates percent inclusion of washed distillery sludge in the diets.

Means in a row with different superscripts differ significantly $(\mathrm{p}<0.01)$.

\section{Feed intake}

During starter phase, maximum (1,503 g) and minimum $(1,398 \mathrm{~g})$ feed intakes were observed in birds fed diets containing 12 and $0 \%$ WDS, respectively (Table 5). During finisher phase, the highest $(\mathrm{p}<0.01)$ feed consumption was observed in birds fed diet containing $8 \%$ WDS while, the lowest $(p>0.01)$ in birds fed diets containing 0 and $4 \%$ WDS. Average feed intake was higher $(\mathrm{p}<0.01)$ in birds fed diet containing $8 \%$ WDS than all other treatments.

\section{Feed conversion ratio}

Average feed conversion ratio of birds fed diets containing $0,4,8$ and $12 \%$ WDS were $1.54,1.53,1.51$ and 1.55 , in the starter phase, $2.44,2.46,2.40$ and 2.38 , in the finisher phase and 1.88, 1.88, 1.89 and 1.88, in the startercum-finisher phase, respectively. Apparently, birds fed diet containing $12 \%$ WDS consumed more feed per unit weight gain than those fed diet containing 0, 4 and $8 \%$ WDS during starter phase, but statistically the difference was nonsignificant. Similarly, during finisher phase, birds fed diet containing 4\% WDS consumed more feed per unit weight gain but statistically, it was non-significant. Overall FCR remained unaffected by WDS supplementation in the diet.

\section{Economics}

Overall, feed cost per kg live weight gains in birds fed diets containing $0,4,8$ and $12 \%$ WDS were $0.62,0.56,0.50$ and 0.48 (US), respectively. This showed that feed cost

Table 6. Effects of different levels of washed distillery sludge on the dressing percentage and slaughter parameters of broiler chickens

\begin{tabular}{lcccc}
\hline \multirow{2}{*}{ Item } & \multicolumn{3}{c}{ WDS $^{1}(\%)$} \\
\cline { 2 - 5 } & 0 & 4 & 65 & 12 \\
\hline Dressing percentage & $65.78 \pm 1.81$ & $65.13 \pm 2.13$ & $65.89 \pm 2.42$ & \\
Slaughter parameters (per 100 g) & & & & \\
$\quad$ Heart weight (mg) & $444.60^{\mathrm{a}} \pm 18.23$ & $401.90^{\mathrm{b}} \pm 21.76$ & $366.00^{\mathrm{b}} \pm 20.36$ & $376.60^{\mathrm{b}} \pm 21.33$ \\
Liver weight (g) & $2.40^{\mathrm{a}} \pm 0.04$ & $2.26^{\mathrm{b}} \pm 0.04$ & $2.13^{\mathrm{c}} \pm 0.09$ & $2.16^{\mathrm{bc} \pm 0.07}$ \\
Gizzard weight (g) & $1.67^{\mathrm{b}} \pm 0.03$ & $1.96^{\mathrm{a}} \pm 0.10$ & $2.10^{\mathrm{a}} \pm 0.05$ & $1.75^{\mathrm{b}} \pm 0.10$ \\
Intestinal length (cm) & $11.13^{\mathrm{a}} \pm 0.43$ & $11.05^{\mathrm{a}} \pm 0.32$ & $9.86^{\mathrm{b}} \pm 0.18$ & $10.75^{\mathrm{a}} \pm 0.26$ \\
Pancreas weight (mg) & $360.30^{\mathrm{a}} \pm 25.17$ & $335.40^{\mathrm{a}} \pm 24.34$ & $335.00^{\mathrm{a}} \pm 23.96$ & $289.70^{\mathrm{b} \pm 13.55}$ \\
Thymus weight (mg) & $589.50 \pm 32.08$ & $532.96 \pm 42.44$ & $503.69 \pm 18.07$ & $541.10 \pm 33.18$ \\
\hline
\end{tabular}

${ }^{1} 0,4,8$ and 12 WDS indicates percent inclusion of washed distillery sludge in the diets.

Means in a row with different superscripts differ significantly $(\mathrm{p}<0.01)$. 
per kg live weight gains decreased significantly with the increase in the level of WDS.

\section{Survivability percentage}

During starter phase, there was $0 \%$ mortality in all birds fed diet with or without WDS which indicates $100 \%$ survivability. Average survivability percentages were 90.00 , 93.33, 96.66 and 100.00 in birds fed 0, 4, 8 and 12\% WDS, respectively during finisher as well as starter-cum-finisher phases.

\section{Dressing percentage and slaughter parameters}

Average dressing percentage in birds fed diets containing $0,4,8$ and $12 \%$ WDS was $65.78,65.13,65.89$ and 66.20, respectively. The highest value was observed in birds fed diets containing 12\% WDS and the lowest in birds fed diets containing 4\% WDS but the difference was statistically non-significant.

Average liver weights per $100 \mathrm{~g}$ of live weights were 2.40, 2.26, 2.12 and $2.16 \mathrm{~g}$ respectively, in birds fed diets containing $0,4,8$ and $12 \%$ WDS. So there was significant reduction $(\mathrm{p}<0.01)$ in liver weights as the level of WDS was increased in the diets. Average gizzard weights per $100 \mathrm{~g}$ live weight gains were $1.67,1.96,2.10$ and $1.75 \mathrm{~g}$ respectively for birds fed diets with $0,4,8$ and $12 \%$ WDS. Minimum and maximum gizzard weight was observed in birds fed diets containing 0 and $8 \%$ WDS, respectively.

Average heart weights per $100 \mathrm{~g}$ live weight gains were 444.60, 401.90, 366.00 and $376.60 \mathrm{mg}$ respectively, for birds fed diets containing 0, 4, 8 and $12 \%$ WDS. Significant decrease $(p>0.01)$ in heart weights was observed in birds fed diets containing WDS. Average thymus weights per 100 $\mathrm{g}$ live weights were 589.50, 532.96, 503.69 and $541.10 \mathrm{mg}$ respectively, for birds fed diets containing 0, 4, 8 and $12 \%$ WDS. The lowest value of thymus weight was observed in birds fed diet containing $8 \%$ WDS while the highest in birds fed diet containing 0\% WDS. However, statistically the difference was non-significant. Average pancreas weights per $100 \mathrm{~g}$ were $360.30,335.40,335.00$ and $289.70 \mathrm{mg}$ respectively, for birds fed diets containing $0,4,8$ and $12 \%$ WDS. The maximum weight of pancreas was observed in birds fed diet containing 0\% WDS which decreased gradually with increasing the levels of WDS. Average intestinal lengths per $100 \mathrm{~g}$ live weights were 11.13, 11.95, 9.855 and 10.75 respectively, for birds fed diets containing $0,4,8$ and $12 \%$ WDS. The diet containing $8 \%$ WDS showed significant decrease in the intestinal length.

\section{DISCUSSION}

\section{Nutritional potential of distillery sludge}

Our findings to use DYS after washing are in concordance with Rameshwari and Karthikeyan (2005) who reported that WDS can be used successfully in poultry diet without any adverse effect. Washing affects most of the nutrients, either by increasing or decreasing their contents. The total mineral content (ash) decreased by $46.19 \%$ as RDS contains higher mineral content and most of these minerals are water soluble (Table 1). During washing, these minerals were solublized in water and were eliminated along with water, resulting in decreased mineral content. This decrease ultimately led to the reciprocal increase in other nutrients including $\mathrm{CP}$, EE, NFE and ME. True protein increased almost twice as that of $\mathrm{CP}$ which was due to the fact that RDS contains non-protein nitrogen (NPN) source i.e. diammonium phosphate which is also water soluble. Reduction in NPN\% results in reciprocal increase in true protein percentage. This indicates that washing reduces the total mineral content, as well as water soluble NPN substances present in RDS. The changes in other nutrients are only the result of reciprocal increase, in order to fill the gap created by the reduction of mineral content and NPN substances. However, no change was observed in either the CF contents or amino acid profiler, as washing didn't affect them. The amino acid profile indicates a superior quality protein. These findings are in agreement with Yalcin et al. (2008) who reported brewing dried yeast as a good source of quality protein.

\section{Weight gain}

Significant improvement in live weight gain was observed as the level of WDS was increased up to $8 \%$. The possible reason for this might be higher feed intake, digestibility and biological value of protein present in WDS. Decreased weight gain at higher level of WDS i.e. $12 \%$ might be due to reduced feed intake which was associated with higher level of nucleic acids (Oliva-Teles and Goncalves, 2001). Similar findings were observed by Khan (2001) who reported that increasing the level of RDS up to $6 \%$ improved weight gain in birds while 9\% RDS had adverse effect on live weight gain. In another study, it was found that inclusion of distillery sludge up to $5 \%$ in bird's diet has no detrimental effects while increasing the level up to $10 \%$ retarded growth (Goto et al., 1974). Similarly, Machalek et al. (1988) reported that replacing soyabean meal with equal amount of brewer's yeast having $48 \% \mathrm{CP}$ resulted in improved weight gain. Other researchers (Churchil and Mohan, 2000; Nilson et al., 2004; Paryad and Mahmoudi, 2008) also found that inclusion of yeast in broiler diets improved weight gain.

\section{Feed consumption}

Significantly higher feed consumption in birds fed diet containing $8 \%$ WDS compared to lower levels of WDS was 
possibly due to the fact that distillery sludge is a rich source of vitamins especially B-complex, oligomonosaccharides (natural aflatoxin binder) and unidentified nutrients, all of which might have contributed to increase the palatability of diet. Our findings are consistent with Gomez and Angeles (2011) who reported that feeding of yeast resulted in better feed intake. Herria and Garcia (1983) found that incorporating yeast up to $7 \%$ in the diet replacing soyabean meal improved feed intake. Khan (2001) also reported that feed intake increased significantly with increasing the level of RDS up to $6 \%$ but above than that, feed intake was reduced. The reason for decreased feed intake in birds fed diet containing $12 \%$ WDS might be due to higher level of nucleic acids (Oliva-Teles and Goncalves, 2001). Rumsey et al. (1991) also found a decline in feed intake with increasing levels of brewer's dried yeast. Zerai et al. (2008) noticed depressed feed intake with increasing the levels of brewer's yeast. The probable reason for this might be higher levels of brewer's yeast (45\%) used to replace fish meal.

\section{Feed conversion ratio}

The results revealed non-significant differences in FCR among diets containing different levels of WDS. Kahraman et al. (1997) also reported non-significant difference among treatment groups supplemented with organic acid (acid dry $3 \mathrm{~g} / \mathrm{kg}$ ), yeast culture (yea sacc1026 $1 \mathrm{~g} / \mathrm{kg}$ ) and organic acid and yeast culture (acid lac dry $3 \mathrm{~g} / \mathrm{kg}$ and yea sacc $10261 \mathrm{~g} / \mathrm{kg}$ ), respectively. Contrary to these, Nilson et al. (2004) found better FCR in birds fed yeast containing diets. Khan (2001) also reported that FCR was significantly improved in diets containing 6\% RDS. Other researchers (Santin et al., 2001; Nilson et al., 2004; Zhang et al., 2005) observed similar findings. This is due to the reason that distillery sludge is a rich source of vitamins, oligomonosaccharides, and some unidentified nutrients, which contributed better FCR.

\section{Economics}

Decrease in feed cost/kg live weight gain with increasing the levels of WDS was due to low cost of production of WDS which was $50 \%$ cheaper than canola meal. Similarly findings were also reported by Magalhaes et al. (2008) who found $14.6 \%$ more profit on feeding yeast in the diet compared to control.

\section{Survivability percentage}

Although survivability percentage increased gradually with increasing the level of WDS but statistically the difference was non-significant. Teeter (1992) also reported that yeast culture had non-significant effect on survivability in birds. Similar findings were also reported by Tovar et al. (2002). Contrary to these, Magalhaes et al. (2008) reported improved survival rate through feeding yeast culture. This is due to the reason that yeast is rich source of oligosaccharides such as glucan which improved neutrophil chemotaxis activity (Murphy et al., 2007). This might have improved phagocytic activity of neutrophils against pathogenic organisms, improving the survivability percentage.

\section{Dressing percentage and slaughter parameters}

The findings showed non-significant difference in the dressing percentage of groups fed diets containing different levels of WDS. Our findings were supported by Kahraman et al. (1997) who also reported non-significant difference in the dressing percentage. Contrary to these findings, Khan (2001) mentioned that dressing percentage was significantly improved in broilers fed diets containing 6\% sun dried RDS

Significant increase in the liver weights was observed with decreasing the WDS level and increasing the canola meal in the diet. The probable reason for this might be either the presence of aflatoxin in the feedstuffs or the presence of allyl-isothiocyanates in the canola meal, both result in liver hyperplasia and as a result of that its weight increases. Liver hyperplasia was not observed in birds fed diets with higher levels of WDS and lower level of canola meal. In such diets allyl-isothiocyanate level was low and mycotoxins (if present) were bound by the oligomonosaccharides, present in WDS. Thus there was significant decrease in the liver weights. Our findings were supported by other researchers (Kinal et al., 1983; Idress, 1998) who reported that the increase in liver weight in broilers fed diets containing higher levels of canola meal, was probably due to a hydrolytic product of glucosinolates (allyl-isothiocyanate) which is present in canola meal and is toxic in nature like other thionamides, resulting in hyperplasia of the liver. Tripathi and Mishra (2008) reported similar findings.

Decreased pancreas weight with increasing the level of WDS might be due to the presence of various digestive enzymes in the distillery sludge. Other researcher (Pettersson and Aman, 1989; Brenes et al., 1993; Viveros et al., 1994; Berwal et al., 2008) also reported that increase in the digestibility of nutrients in the presence of enzymes in the feed can cause a reduction in the weight of pancreas.

Significant increase in the intestinal length was observed as the level of WDS was decreased in the diet. Possibly, this was related with modification in the intestinal length to accommodate higher fiber content/absence of enzymes in diets, not containing WDS. Similar findings were also reported by other researchers (Hetland and Svihus, 2001; Hetland et al., 2002, 2003). As the level of WDS was increased in the diet, it resulted in significant reduction in the intestinal length due to decreased fiber content and 
increased level of digestive enzymes, as WDS is a good source of digestive enzymes. Presence of enzymes in the feed can cause a reduction in the digestive tract size (Pettersson and Aman, 1989; Berwal et al., 2008).

\section{CONCLUSION}

Feeding increasing levels of distillery yeast sludge in the broiler diets resulted in improved weight gain and feed intake. However, inclusion of distillery yeast sludge up to $8 \%$ showed better results in terms of weight gain and economics. It resulted in significant reduction in the intestinal length and pancreas weight due to decreased fiber content and increased digestive enzymes, as WDS is a good source of digestive enzymes. Dressing percentage remained unaffected by feeding sludge in the diet. This indicates that distillery yeast sludge can be included in the poultry diet up to $8 \%$ without any deleterious effect on the performance of the birds.

\section{ACKNOWLEDGEMENTS}

This study was completed at the Institute of Animal Nutrition and Feed Technology (University of Agriculture, Faisalabad, Pakistan). The authors thank Mr. Jamal, Crescent Sugar Mill and Laboratory staff of the Institute for their cooperation in this study.

\section{REFERENCES}

Ali, S. 2004. Lysine enrichment of distillery sludge, its biological evaluation and detoxification potential against aflatoxin $\mathrm{B}_{1}$. Ph.D. Thesis, Dept. Chem. University of Agriculture, Faisalabad, Pakistan.

AOAC. 1990. Official methods of analysis. 15th edn. Association of Official Analytical Chemists, Arlington, Virginia, USA.

Berwal, R. S., O. P. Lohan and S. Shiag Zile. 2008. Effect of dietary crude fibre levels and enzyme supplementation on performance and carcass characteristics of broiler chicks. Indian J. Poult. Sci. 43:5529.

Brenes, A., M. Smith, W. Guenter and R. R. Marqurdt. 1993. Effect of enzyme supplementation on the performance and digestive tract size of broiler chickens fed wheat and barley based diets. Poult. Sci. 72:1731-1739.

Bustamante, M. A., R. Moral, C. Paredes, A. Perez-Espinosa, J. Moreno-Caselles and M. D. Perez-Murcia. 2008. Agrochemical characterization of the solid by-products and residues from the winery and distillery industry. Waste Manag. 28:372-380.

Churchil, R. and B. Mohan. 2000. Effect of supplementation of broiler diets with live yeast culure. Cheiron. 29:23-27.

Economic Survey of Pakistan, 2009-2010. Govt. of Pakistan. Finance Division, Economic Advisor's Wing, Islamabad.

Esonu, B. O., U. D. Ogbonna, G. A. Anyanwu, O. O. Emenalom, M. C. Uchegbu, E. B. Etuk and A. B. I. Udedibie. 2006. Evaluation of performance, organ characteristics and economic analysis of broiler finisher fed dried rumen digesta. Int. J. Poult. Sci. 5:1116-1118.

Goto, I., Y. Masuda and M. Senuki. 1974. Utilization of brewers activated sludge for animal feed. 1. Digestibility as poultry feed and effect of growth of chickens. Pages 115-118 in Science Bulletin of the Faculty of Agri. Kyushu University, Japan.

Haldar, S., T. K. Ghosh, Toshiwati and M. R. Bedford. 2011. Effects of yeast (Saccharomyces cerevisiae) and yeast protein concentrate on production performance of broiler chickens exposed to heat stress and challenged with Salmonella enteritidis. Anim. Feed Sci. Technol. 168:61-71.

Herria, J. A. and A. Garcia. 1983. Substitution of levels of soyabean meal by wheat (A) in diet for broilers fed $20 \%$ torrula yeast. Cuban J. Agric. Sci. 17:299-306.

Hetland, H. and B. Svihus. 2001. Effect of oat hulls on performance, gut capacity and feed passage time in broiler chicken. Br. Poult. Sci. 42:354-361.

Hetland, H., B. Svilus and V. Olaisen. 2002. Effect of feeding whole cereals on performance, starch digestibility and duodenal particle size distribution in broiler chickens. Br. Poult. Sci. 43:416-423.

Hetland, H., B. Svilus and A. Krogdahl. 2003. Effect of oat hulls and wood shavings on digestion in broilers and layers fed diets based on whole or ground wheat. Br. Poult. Sci. 44:275-282.

Idrees, Z. 1998. Use of different levels of canola meal in broiler diets as a replacement of soyabean meal. M.Sc. (Hons.) Thesis, University of Agriculture, Faisalabad, Pakistan.

Kahraman, R., I. Abas, K. Bostan, A. Tanor, N. Kocabagli and M. Alp. 1997. Effect of organic acids and yeast culture on performance, ileum $\mathrm{pH}$ and enterobacteriaceae population of broiler. Pendik Veteriner Mikrobiyoloji Dergisi 28:171-180.

Khan, M. L. 2001. Poultry feeds and nutrition. Kitabistan Publishing Co. 38-Urdu Bazar, Lahore.

Kinal, S., A. Kroliczek, T. Gawara and R. Arciszewska. 1983. Effect of Janpol rapeseed on digestibility of nutrients and production indices of broiler chicken. Nutr. Abstr. Rev. 53:2731.

Machalek, E., Z. Hudskey, D. Dostalova and J. C. Cibulka. 1988. The use of yeast protein vitex in fattening broiler chickens. Zivocisna Vyroba 33:1037-1046.

Magalhaes, V. J. A., F. Susca, F. S. Lima, A. F. Branco, I. Yoon and J. E. P. Santos. 2008. Effect of feeding yeast culture on performance, health, and immunocompetence of dairy calves. J. Dairy Sci. 91:1497-1509.

Murphy, E. A., J. M. Davis, A. S. Brown, M. D. Carmichael, A. Ghaffar and E. P. Mayer. 2007. Oat $\beta$-glucan effects on neutrophil respiratory burst activity following exercise. Med. Sci. Sports Exerc. 39:639-644.

National Research Council. 2001. Nutrient requirements of poultry. 11th revised ed. National Academy Press, Washington, DC, USA.

Nilson, A., J. M. F. Peralta and R. D. Miazzo. 2004. Use of brewers yeast $(S$. cerevisiae) to replace part of the vitamin mineral premix in finisher broiler diets. XXII Worlds Poultry Congress, Istanbul, Turkey

Nukamp, H. J. 1965. Some remarks about the determination of the heat if combustion and the carbon content of urine. Fida EAAP, Publ. 11th ed. Blaxter, K.L., Academic Press. 
Oliva-Teles, A. and P. Goncalves. 2001. Partial replacement of fish meal by brewers yeast Saccaromyces cerevisae in diets for sea bass Dicentrarchus labrax juveniles. Aquaculture 202:269-278.

Paryad, A. and M. Mahmoudi. 2008. Effect of different levels of supplemental yeast (Saccharomyces cerevisiae) on performance, blood constituents and carcass characteristics of broiler chicks. Afr. J. Agric. Res. 3:835-842.

Pelícia, V. C., J. R. Sartori, K. C. Zavarize, A. C. Pezzato, A. C. Stradiotti, P. C. Araujo, M. A. O. Mituo and L. A. Madeira. 2010. Effect of nucleotides on broiler performance and carcass yield. Revista Brasileira de Ciência Avícola. 12:31-34.

Pettersson, D. and P. Aman. 1989. Enzyme supplementation of poultry diets containing rye and wheat. Br. J. Nutr. 62:139-149.

Rameshwari, K. S. and S. Karthikeyan. 2005. Distillery yeast sludge (DYS) as an alternative feed resource in poultry. Int. J. Poult. Sci. 4:787-789.

Rumsey, G. L., J. E. Kinsella, K. J. Shetty and S. G. Hughes. 1991. Effect of high dietary concentdiets of brewers dried yeast on growth performance and liver uricase in rainbow trout, Oncorhynchus mykiss. Anim. Feed Sci. Technol. 33:177-183.

Gomez, S. and M. de L. Angeles. 2011. Effect of an enzymatically hydrolyzed yeast and yeast culture combined with flavomycin and monensin on finishing broiler chickens. Int. J. Poult. Sci. 10:433-439.

Santin, E., A. Maiorka, M. Macari, M. Grecco, J. C. Sanchezi, T. M. Okada and A. M. Myasaka. 2001. Performance and intestinal mucosa development of broiler chickens fed diets containing Saccharomyces cerevisiae cell wall. J. Appl. Poult. Res. 10:236-244.

Shahzad, M. A. and M. Rajoka. 2011. Single cell protein production from Aspergillus terreus and its evaluation in broiler chicks. Int. J. Biosci. Biochem. Bioinform. 1:137-141.

Silva, V. K., J. Della Torre da Silva, K. A. A. Torres, D. de Faria Filho, F. Hirota Hada and V. M. Barbosa de Moraes. 2009. Humoral immune response of broilers fed diets containing yeast extract and prebiotics in the prestarter phase and raised at different temperatures. J. Appl. Poult. Res. 18:530-540.
Steel, R. G. D., J. H. Torrie and D. A. Dickey. 1997. Principles and procedures of statistics. A Biometric Approach 3rd ed. McGraw-Hill, Boston.

Teeter, R. 1992. Effect of yeast culture in broilers under heat stress and non-specific antigen challenge yeast culture poultry research report. Deptt. Animal Science, Oklahoma State University, Stillwater, Oklahoma.

Tovar, D., J. Zambonino, C. Cahu, F. J. Gatesoupe, R. Va zquezJua rez and R. Le sel. 2002. Effect of live yeast incorpodiet in compound diet on digestive enzyme activity in sea bass (Dicentrarchus labrax) larvae. Aquaculture 204:113-123.

Tripathi, M. K. and A. S. Mishra. 2008. Glucosinolates in animal nutrition. A review. Anim. Feed Sci. Technol. 132:1-27.

Viveros, A., A. Brenes, M. Pizarro and M. Castano. 1994. Effect of enzyme supplementation of a diet based on barley and autoclave treatment, on apparent digestibility, growth performance and gut morphology of broilers. Anim. Feed Sci. Technol. 48:237-251.

Ware, S. A. 1977. Single cell protein and other food recovery technologies from waste. Municipal environmental research laboratory. Office of R. \& D. U.S. E.P.A. Cincinnati, Ohio.

Yalcın, S., H. Erol, B. O. Zsoy, I. Onbasılar and S. Yalcin. 2008. Effects of the usage of dried brewing yeast in the diets on the performance, egg traits and blood parameters in quails. Animal 2:1780-1785

Zerai, D. B., K. M. Fitzsimmons, R. J. Collier and G. C. Duff. 2008. Evaluation of brewer's waste as partial replacement of fish meal protein in nile tilapia, oreochromis niloticus, diets. J. World Aquac. Soc. 39:556-564.

Zhang, A. W., B. D. Lee, S. K. Lee, K. W. Lee, G. H. An, K. B. Song and C. H. Lee. 2005. Effects of yeast (Saccharomyces cerevisiae) cell components on growth performance, meat quality, and ileal mucosa development of broiler chicks. J. Poult. Sci. 84:1015-1021. 